\title{
PERAN LEMBAGA MASYARAKAT ADAT (LMA) SUKU MARIND DALAM PENYELESAIAN SENGKETA TANAH ULAYAT DI KOTA MERAUKE
}

\section{Erwin Nugraha Purnama, Kismartini, Retno Sunu Astuti}

Universitas Diponegoro (Undip) Semarang Jawa Tengah, Indonesia

Email: erwinpurnamasiregar@gmail.com,kis_martini@yahoo.co.id, retnosunu@gmail.com

\section{Abstract}

This study aims to identify the Role of Institutions of Indigenous Marind in Dispute resolution Customary land in the City of Merauke as well as analyze the factors that affect the role of Institutions of Indigenous Marind in dispute resolution Customary land in the Town of Merauke. Methods a qualitative descriptive study using primary data collection techniques (observation and interviews) and secondary data. Data collection techniques used literature study and field study observation and Interviews. The results of the research show that the Role of Institutions of Indigenous Peoples in Dispute resolution Customary Land in the Town of Merauke is still not optimal, there are still many cases of dispute is a communal land that has not been resolved and there are still a variety of indicators that could potentially lead to the occurrence of problems related to communal land later in the day, indicators are; yet its systematic data collection on Institutions of indigenous Peoples related to land rights, the absence of mapping in writing related to the boundaries of indigenous territories. The recommendations given; Mapping the territory and boundaries of indigenous territories are outlined in writing in the Map of the custom region, Making the administrative system at the Institute of Indigenous Peoples related to the status of customary land that have not been released, Do data collection and mapping accurately related to the completeness of the administration of the ownership of communal Land, Create a discussion forum involving Local government Agencies, Institutions and Communities, to be able to make a draft of the legal products that regulate the specific layout of indigenous territories.

Keywords: role; the organization of indigenous peoples; customary land disputes

\section{Abstrak}

Penelitian ini bertujuan mengidentifikasi Peran Lembaga Masyarakat Adat Suku Marind dalam Penyelesaian Sengketa tanah Ulayat di Kota Merauke serta menganalisis faktor yang mempengaruhi peran Lembaga Masyarakat Adat Suku Marind dalam penyelesaian sengketa tanah Ulayat di Kota Merauke. Metode penelitian deskriptif kualitatif menggunakan teknik pengumpulan data primer (observasi dan wawancara) serta data sekunder. Teknik pengumpulan data yang digunakan study pustaka dan study lapangan berupa observasi dan Wawancara. Hasil penelitian menunjukkan bahwa Peran Lembaga Masyarakat Adat dalam Penyelesaian Sengketa Tanah Ulayat di Kota Merauke masih belum optimal, masih banyak kasus sengketa tanah ulayat yang belum terselesaikan dan masih ada 
berbagai indikator yang berpotensi menyebabkan terjadinya permasalahan terkait tanah ulayat. Di kemudian hari, indikator tersebut adalah; belum sistematisnya pendataan Lembaga Masyarakat adat terkait hak ulayat, belum adanya pemetaan secara tertulis terkait batas wilayah adat. Rekomendasi yang diberikan; Melakukan pemetaan wilayah dan batas wilayah adat yang dituangkan secara tertulis dalam Peta wilayah adat, merapihkan sistem administrasi di Lembaga Masyarakat Adat terkait status tanah ulayat yang belum dan yang telah dilepaskan, Melakukan pendataan dan pemetaan secara akurat terkait kelengkapan administrasi kepemilikkan Tanah ulayat, Membuat forum diskusi dengan melibatkan Instansi pemerintah Daerah, Lembaga Masyarakat Adat dan masyarakat, untuk dapat membuat sebuah rancangan produk hukum yang mengatur secara spesifik tata wilayah adat.

Kata Kunci: peran; lembaga masyarakat adat; sengketa tanah ulayat

\section{Pendahuluan}

Tanah merupakan sumber daya penting dan strategis, hal ini dikarenakan menyangkut hajat hidup manusia yang sangat mendasar. Berbagai ragam sengketa hak atas tanah terus mengalami perkembangan dari waktu ke waktu, baik yang menyangkut sengketa perebutan hak, sengketa status tanah maupun bentuk-bentuk sengketa yang lainnya. Sengketa tersebut melibatkan banyak kesatuan masyarakat. Sengketa tanah yang timbul, seringkali terjadi akibat letak dan batas bidang-bidang tanah yang tidak benar. Menurut Kementerian Agraria dan Tata Ruang/Badan Pertanahan Nasional (ATR/BPN), bukti kepemilikan dan masih tingginya ketimpangan penguasaan tanah menjadi akar permasalahan sengketa tanah di Indonesia. Sesuai data yang ada, sengketa tanah yang sering terjadi yaitu antar-perorangan 6.071 kasus $(56,20 \%)$, masyarakat dan pemerintah 2.866 kasus $(26,53 \%)$, perorangan dan badan hukum 1.668 kasus $(15,44 \%)$, antar-badan hukum 131 kasus $(1,21 \%)$, dan antar-kelompok masyarakat sebanyak 66 kasus $(0,61 \%)$ (Hutapea, 2018).

Motif yang melatar belakangi penyebab kasus-kasus tanah sangat bervariasi antara lain kurang tertibnya administrasi pertanahan di masa lampau, harga tanah yang meningkat dengan cepat, kondisi masyarakat yang semakin menyadari dan mengerti akan kepentingan haknya, masih ada oknum-oknum pemerintah yang belum dapat menangkap aspirasi masyarakat, dan adanya pihak yang menggunakan kesempatan untuk mencari keuntungan materil yang tidak wajar atau menggunakan untuk kepentingan politik (Chomzah, 2004).

Bagi masyarakat Papua, tanah memiliki arti yang sangat penting. Pandangan filosofis masyarakat Papua menganggap tanah sebagai "Mama/Ibu", sehingga harus dipertahankan dan tidak dapat diperjual belikan. Masyarakat adat di Papua menyatakan bahwa semua tanah di Papua merupakan tanah hak ulayat, kecuali yang telah dialihkan dengan proses pelepasan adat, dengan di terbitkannya surat pelepasan tanah Adat oleh Lembaga Masyarakat Adat (LMA). Lembaga adat adalah sebuah organisasi/wadah yang dibentuk secara turun temurun maupun yang telah tumbuh dan berkembang di dalam sejarah masyarakat tersebut atau dalam hukum masyarakat adat tertentu dalam wilayah hukum adat tersebut yang berhak dan berwenang mengatur, mengurus dan 
menyelesaikan berbagai permasalahan kehidupan yang berkaitan dengan adat istiadat dan hukum setempat (Peraturan Daerah Kabupaten Merauke Nomor 4 Tahun 2013 Tentang Pemberdayaan, Perlindungan dan Pengembangan Adat Istiadat Serta Lembaga Adat, 2013).

Lembaga Masyarakat Adat (LMA) suku Marind merupakan suatu badan kepengurusan dan pelaksana yang memiliki peran untuk mengangkat aspek sosial kebudayaan masyarakat Marind dalam bagian wilayah adatnya, sehingga norma-norma budaya adat yang sangat tinggi nilainya dapat diangkat serta dilestarikan. Lembaga Masyarakat Adat merupakan pihak yang berwenang untuk menerbitkan surat pelepasan tanah adat di Merauke, sehingga ketika kemudian hari terjadi masalah terkait tanah ulayat, maka Lembaga Masyarakat adat berperan penting dalam proses penyelesaiannya.

Di Kota Merauke kerap kali terjadi sengketa tanah ulayat, berdasarkan informasi yang diperoleh dari Polres Merauke jumlah sengketa pertanahan 6 (enam) tahun terakhir di Merauke berjumlah 77 Kasus dengan rincian: Tahun 2014:12 kasus, tahun 2015: 8 kasus, tahun 2016: 13 kasus, tahun 2017: 8 kasus, tahun 2018: 11 kasus, dan tahun 2019: 25 kasus. Permasalahan-permasalahan yang teridentifikasi antara lain, masalah hak ulayat, sengketa batas, kekeliruan petunjuk batas dan pembayaran pelepasan tanah yang belum diselesaikan (Unit Bina Masyarakat Polres Merauke, 2019).

Sudah dilakukan berbagai penelitian tentang peran Lembaga Adat dalam Penyelesaian Sengketa tanah ulayat ini (Goti, 2014); (Aris et al., 2014); (Sopian, 2015); (Rukuni et al., 2015) yang menunjukkan bahwa Lembaga Adat memiliki peranan penting dalam menyelesaikan sengketa adat di wilayah Kabupaten Ngada (Nusa Tenggara Timur), Kabupaten Sanggau (Kalimantan Barat), Flores (Nusa Tenggara Timur) dan Distrik Bikita (Zimbabwe) dengan hasil yang bervariasi. Sebagian berhasil, sebagian masih belum optimal dan mengalami berbagai hambatan misalnya ketidakjelasan kepemilikan batas tanah, adanya klaim dari negara atau pemerintah, kehilangan saksi atau pelaku sejarah, melunturnya nilai budaya dan kurangnya sosialisasi terhadap masyarakat terkait keberadaan dan status dari tanah ulayat tersebut, dan beberapa pemimpin tradisional bias dalam pelaksanaan tugas-tugas mandat mereka, terutama ketika berhadapan dengan masalah partai politik.

Perbedaan penelitian ini dengan penelitian sebelumnya adalah penelitian Peran Lembaga Masyarakat Adat (LMA) Suku Marind Dalam Penyelesaian Sengketa Tanah Ulayat Di Kota Merauke ini berfokus pada dua hal yaitu: (1) Peran Lembaga Masyarakat

Adat (LMA) Suku Marind Dalam Penyelesaian Sengketa Tanah Ulayat Di Kota Merauke, dan (2) Faktor apa saja yang mempengaruhi peran Lembaga Masyarakat Adat dalam penyelesaian sengketa tanah Ulayat Suku Marind di Kota Merauke.

\section{Metode Penelitian}

Penelitian ini merupakan penelitian deskriptif dengan pendekatan kualitatif dan berusaha untuk menganalisis Peran Lembaga Masyarakat Adat (LMA) Suku Marind Dalam Penyelesaian Sengketa Tanah Ulayat Di Kota Merauke. Instrumen dalam menelitian ini menggunakan daftar pertanyaan (interview guide) serta telaah terhadap 
dokumen-dokumen pendukung lainnya. Subjek penelitian yaitu informan yang dipilih dengan teknik purposive sampling, yaitu Lembaga Masyarakat Adat (LMA) Marind Imbuti Merauke, Lembaga Masyarakat Adat Kabupaten Merauke, Badan Pertanahan Kabupaten Merauke, Pengadilan Negeri Merauke, Notaris/PPAT, dan Masyarakat Kota Merauke. Teknik pengumpulan data melalui studi pustaka atau pengumpulan data dengan melakukan serangkaian kegiatan membaca, menelaah dan mengutip dari bahan kepustakaan serta pengkajian terhadap ketentuan peraturan perundang-undangan yang berkaitan dengan pokok bahasan, observasi, wawancara mendalam dan dokumentasi. Teknik analisis data dalam penelitian ini data yang terkumpul akan diolah dengan menggunakan metode deskriptif kualitatif yaitu mengumpulkan data berdasarkan faktorfaktor yang menjadi pendukung terhadap objek penelitian, kemudian menganalisa faktor-faktor tersebut (Arikunto, 2010), kemudian pengolahan data tersebut dilakukan dengan Data Reduction (Data Reduksi), Data Display (Penyajian Data), dan Conclusions Drawing/Verifacition (Penarikan Kesimpulan/Verifikasi).

\section{Hasil dan Pembahasan}

Dari waktu ke waktu berbagai ragam sengketa hak atas tanah mengalami perkembangan, baik yang menyangkut sengketa perebutan hak, sengketa status tanah maupun bentuk bentuk sengketa yang lainnya. Di Kota Merauke kerap kali terjadi sengketa tanah ulayat dikalangan masyarakat, seperti masalah hak ulayat, sengketa batas, kekeliruan petunjuk batas dan pembayaran pelepasan tanah yang belum diselesaikan. Bahkan beberapa kasus terjadi terhadap fasilitas publik yang sangat urgent seperti Sekolah, gedung dan lahan Dinas Kesehatan yang seharusnya bebas dari hal-hal yang demikian mengingat kedua objek tersebut merupakan objek vital.

Berdasarkan informasi yang diperoleh dari Unit Bina Mitra Polres Merauke terkait jumlah sengketa pertanahan 6 (enam) tahun terakhir yang terjadi di Merauke berjumlah 77 Kasus dengan rincian sebagai berikut: Tahun 2014 terjadi 12 kasus, tahun 2015 terjadi 8 kasus, tahun 2016 terjadi 13 kasus, tahun 2017 terjadi 8 kasus, tahun 2018 terjadi 11 kasus, dan tahun 2019 terjadi 25 kasus.

Pada dasarnya masyarakat adat di Papua menyatakan bahwa semua tanah di Papua merupakan tanah hak ulayat, kecuali yang telah dialihkan dengan proses pelepasan adat, dengan diterbitkannya surat pelepasan tanah Adat oleh Lembaga Masyarakat Adat. Lembaga Masyarakat Adat suku Marind merupakan suatu badan kepengurusan dan pelaksana yang memiliki peran untuk mengangkat aspek sosial kebudayaan masyarakat Marind dalam bagian wilayah adatnya, sehingga norma-norma budaya adat yang sangat tinggi nilainya dapat diangkat serta dilestarian. Tugas pokok Lembaga Masyarakat Adat yaitu senantiasa menjaga hubungan antara masyarakat dan pemerintah didalam melakukan segala aktifitas pengembangan dan secara langsung Lembaga Masyarakat Adat ini dapat menyalurkan aspirasi-aspirasi serta dapat mensosialisasikan program-program yang akan dilaksanakan oleh pemerintah dalam masyarakat itu sendiri. 
Untuk mengidentifikasi peran Lembaga Masyarakat Adat Suku Marind dalam penyelesaian sengketa tanah ulayat di Kota Merauke dilakukan dengan menganalisis indikator peran Lembaga Masyarakat Adat suku Marind yaitu: Mendata hak-hak milik dan menginventarisir hak-hak milik, menyelesaikan perselisihan yang menyangkut Adat, memusyawarahkan masalah-masalah Adat, dan sebagai penengah kasus-kasus Adat.

\section{A. Peran Lembaga Masyarakat Adat dalam penyelesaian Sengketa Tanah Ulayat Di Kota Merauke}

1. Mendata hak-hak milik dan menginventarisir hak-hak milik

Mendata dan menginventarisir hak-hak milik sebuah kebudayaan sangatlah penting, hal ini dikarenakan selain dapat mengetahui kekayaan budaya apa saja yang dimiliki, dengan mendata dan menginventarisir hak milik terutama terkait dengan hak ulayat dapat mencegah terjadinya sengketa tentang kepemilikkan suatu tanah ulayat. Lembaga Masyarakat Adat menyatakan bahwa mereka telah melakukan pendataan hak-hak ulayat dengan melihat batas-batas hak ulayat sebagaimana telah dilakukan secara turun-temurun oleh masyarakat adat, yaitu dengan melihat tanda-tanda alam dan nama tempat sesuai Marga yang ada sebagai batas wilayah ulayat, selain itu pihak LMA juga berkoordinasi dengan masing-masing ketua Marga untuk mengetahui wilayah ulayat masing-masing Marga.

Kendala yang ditemui pada proses pendataan dan inventarisasi hak-hak milik adalah masih terdapat transaksi jual beli yang dilakukan tanpa melalui Lembaga Adat, sehingga menimbulkan permasalahan dikemudian hari. Hal ini dikarenakan transaksi jual-beli tanpa melalui Lembaga adat kerap kali tidak ada bukti tertulis, dimana seharusnya setiap transaksi jual beli tanah ulayat harus disertai dengan surat pelepasan adat yang dikeluarkan oleh Lembaga Masyarakat Adat.

Tanggapan berbeda dari masyarakat menurut mereka selama ini belum ada pendataan yang dilakukan oleh pihak LMA terkait tanah ulayat tersebut, menurut mereka sejauh ini peran Lembaga Masyarakat Adat dalam mendata hak-hak milik dan menginventarisir hak-hak milik masih belum tercapai, karena masih banyak terdapat kasus sengketa kepemilikkan hak atas tanah ulayat, bahkan masih di dapati kasus tumpang tindihnya surat pelepasan adat dimana satu objek tanah memiliki dua surat pelepasan adat dengan orang yang berbeda, pada akhirnya hal tersebut menimbulkan konflik antara masyarakat yang sama-sama merasa memiliki hak atas tanah tersebut.

2. Menyelesaikan perselisihan yang menyangkut Adat

Penyelesaian terhadap suatu perkara dalam hukum adat merupakan cara yang sangat efektif jika ditinjau secara sosial. Artinya, kemungkinan untuk selesai dalam suatu perkara sangatlah besar. Hal ini karena masyarakat sudah terbiasa dengan hukum adat yang berlaku. Dengan berbagai macam kasus sengketa yang terjadi terkait dengan tanah ulayat, Lembaga Masyarakat Adat dituntut agar dapat mengambil peran dalam penyelesaian perselisihan yang 
terjadi. Terkait penyelesaian sengketa tanah adat seperti "surat pelepasan diatas pelepasan", langkah-langkah yang diambil oleh Lembaga Masyarakat Adat adalah melalui peradilan adat, Lembaga Masyarakat Adat akan mengamankan Pihak pertama sebagai pemilik tanah tersebut dan pihak yang lain dinyatakan gugur.

Meskipun belum optimal, sejauh ini Lembaga Masyarakat Adat telah melakukan berbagai upaya penyelesaian terkait sengketa tanah ulayat, dibuktikan dengan pernyataan masyarakat yang menyatakan bahwa sejauh ini Lembaga Masyarakat Adat telah cukup bisa menyelesaikan perselisihan menyangkut permasalahan adat, namun belum maksimal karena masih terdapat cukup banyak permasalahan-permasalahan yang belum dapat diselesaikan, bahkan pada beberapa kasus yang terjadi Lembaga Masyarakat Adat belum dapat menjalankan fungsinya sebagai mediator secara optimal ketikat terjadi permasalahan sengketa, hal ini dibuktikan dengan masih terjadi berbagai aksi "pemalangan" terhadap fasilitas-fasilitas umum yang bermasalah dengan hak ulayat.

3. Memusyawarahkan masalah-masalah Adat

Dalam menghadapi dan memecahkan sebuah permasalahan bersama sangat perlu menegakkan musyawarah. Semakin besar suatu kelompok maka semakin perlu ditegakkannya musyawarah. Cara bermusyawarah, lembaga permusyawaratan yang perlu dibentuk, cara pengambilan keputusan, cara pelaksanaan keputusan musyawarah, dan aspek-aspek tatalaksana lainnya ditentukan oleh kelompok bersangkutan untuk mengaturnya. Pentingnya Musyawarah dalam kehidupan masyarakat, Abdullah Hamid Ismail al-Anshori dalam bukunya "Al-Syura wa Asaruha fi al-Demokratiyah" (Hanafi, 2013) mengutip dan mengemukakan arti penting musyawarah yang dapat disimpulkan sebagai berikut. "Musyawarah dapat mewujudkan kesatuan bangsa, melatih kegiatan otak dalam berfikir, dan sebagai jalan menuju kepada kebenaran yang mengandung kebaikan dan keberkatan”. Musyawarah dilaksanakan sebagai upaya untuk mengetahui dan mengungkapkan pendapat-pendapat dari semua pihak yang terlibat dengan tujuan mencapai kebenaran yang sesungguhnya serta kejelasan dalam setiap permasalahan.

Peradilan adat di Indonesia berlangsung melalui suatu mekanisme tradisional dalam forum musyawarah adat ("sidang adat" atau "rapat adat") yang diberbagai tempat di Indonesia disebut dengan ungkapan khas masing-masing daerah. Di dalam musyawarah tersebut, peranan kepala-kepala adat sangatlah penting dan menonjol, yaitu sebagai pemimpin musyawarah (Sudantra et al., 2017).

Musyawarah Adat merupakan sarana untuk memperkokoh landasan lokal untuk menyelesaikan kasus yang menyangkut masalah adat, diantaranya mengenai sengketa tanah Ulayat, musyawarah dilakukan untuk mencari jalan keluar dan mendapatkan kesepakatan bersama untuk menyelesaikan suatu 
permasalahan. Keberadaan Lembaga Masyarakat Adat ini diharapkan dapat menjadi alternatif penyelesaian sengketa bagi masyarakat yang memiliki kasus yang menyangkut adat, dengan penyelesaian sengketa alternatif modern dimana musyawarah menjadi model umum dan utama dalam proses penyelesaian sengketa.

Namun sejauh ini Lembaga Masyarakat Adat belum sepenuhnya menjalankan fungsi sebagai mediator dalam rangka rekonsiliasi dan konsolidasi para pihak melalui proses penemuan putusan yang dapat melegakan semua pihak, karena pada dasarnya keputusan diambil secara sukarela oleh para pihak namun pada akhirnya masih banyak permasalahan yang belum menemukan titik tengah penyelesaian.

4. Sebagai penengah kasus-kasus Adat

Istilah mediasi berasal dari bahasa latin, mediare yang berarti ada di tengah (Abbas, 2011). Secara istilah ada beberapa pengertian diantaranya, menurut Takdir Rahmadi (Rahmadi, 2011), mediasi adalah suatu proses penyelesaian sengketa antara dua pihak atau lebih melalui perundingan atau cara mufakat dengan bantuan pihak netral yang tidak memiliki kewenangan memutus. Sedangkan dalam Peraturan Mahakimah Agung Nomor 1 Tahun 2008 menyebutkan Mediasi merupakan salah satu proses penyelesaian sengketa yang lebih cepat dan murah, serta dapat memberi akses lebih besar kepada para pihak menemukan penyelesaian yang memuaskan dan memenuhi rasa keadilan. (Peraturan Mahakimah Agung Nomor 1 Tahun 2008 Tentang Prosedur Mediasi di Pengadilan, 2008).

Kasus sengketa tanah ulayat terjadi ketika adanya klaim batas tanah oleh satu pihak terhadap tanah milik pihak lain. Lembaga Masyarakat Adat dituntut untuk bersikap dan memposisikan diri sebagai pihak yang netral sehingga dalam penyelesaian perselisihan pada akhirnya akan mendapat solusi terbaik untuk kedua belah pihak sehingga tidak ada pihak yang merasa dimenangkan dan tidak ada pihak yang merasa dikalahkan.

Sengketa tanah ulayat masih terjadi, sejauh ini Lembaga Masyarakat Adat telah melakukan upaya-upaya sebagai mediator dalam penyelesaian kasus sengketa tanah ulayat yang terjadi. Upaya yang ditempuh oleh Lembaga Masyarakat Adat antara lain dengan mempertemukan kedua belah pihak yang bersengketa, kemudian melakukan musyawarah guna mencari solusi yang terbaik. Meski demikian masih banyak kasus sengketa tanah ulayat yang belum dapat diselesaikan meski telah dilakukan musyawarah, dan pada akhirnya masalah ini dikembalikan kepada kedua belah pihak untuk diselesaikan secara kekeluargaan.

\section{B. Faktor Yang Mempengaruhi Peran Lembaga Masyarakat Adat (LMA) dalam Penyelesaian Sengketa Tanah Ulayat Di Kota Merauke}

Unsur-unsur yang perlu diperhatikan dalam mengetahui faktor penentu keberhasilan peran aktor dalam implementasi suatu kebijakan yaitu; Perspektif 
Aktor, Aksesibilitas Aktor, dan Kemampuan Aktor dalam Mengambil Tindakan. (Yakin, 2013).

1. Perspektif Aktor

Perspektif aktor dalam hal ini adalah bagaimana cara pandang dan sikap Lembaga Masyarakat Adat (LMA) dalam menilai dan memahami suatu fenomena kejadian atau masalah yang terjadi. Seberapa jauh pemahaman aktor terhadap permasalahan yang terjadi sangatlah penting dalam upaya penentuan tindakan penyelesaian permasalahan tersebut.

Berdasarkan perspektif aktor, permasalahan terkait tanah ulayat memiliki sejarah yang panjang. Permasalahan terkait sengketa tanah ulayat disebabkan beberapa hal diantaranya; permasalahan administrasi di masa lalu, dimana pada saat itu belum terbentuk Lembaga Masyarakat Adat (LMA), sehingga transaksi pemindahan kepemilikan tanah ulayat cenderung berdasarkan sosial karena kedekatan pemilik tanah dengan pihak lain, kemudian terjadilah transaksi pemindahan kepemilikan tanah ulayat tersebut dan prosesi tersebut tanpa ada bukti tertulis, sehingga dikemudian hari ahli waris dari pemilik tanah adat sebelumnya mengklaim memiliki tanah tersebut.

Akibat dari permasalahan administrasi tersebut, timbullah berbagai permasalahan sengketa tanah di Kota Merauke seperti sengketa karena ada surat pelepasan diatas pelepasan jadi ada 2 (dua) surat pelepasan untuk satu obyek tanah, ada juga sengketa pelepasan dengan sertifikat. Selain itu penyebab terjadinya konflik pertanahan seringkali terjadi karena status kepemilikan tanah atau wilayah tersebut, hal ini dikarenakan belum adanya pemetaan secara tertulis terkait dengan batasan wilayah adat. Hingga saat ini untuk menentukan batasan wilayah, cara yang digunakan masih dengan kepercayaan turun-temurun yaitu dengan nama tempat, dan keadaan alam seperti batas pohon, atau batas sungai. Hal ini tentunya akan cenderung berpotensi menimbulkan konflik dikemudian hari, karena keadaan alam tentunya akan berubah dari waktu ke waktu hal ini tentunya akan mempengaruhi posisi batas-batas wilayah tersebut, sehingga sangat perlu untuk membuat batasan-batasan wilayah adat tersebut dalam bentuk tertulis berupa sebuah peta wilayah adat.

Terkait administrasi pembuatan Surat pelepasan tanah adat sebagai syarat pembuatan sertifikat tanah, terjadi perbedaan perspektif antara pihak pemerintah dalam hal ini pihak Badan Pertanahan Nasional yang menyatakan bahwa surat pelepasan adat yang dikeluarkan oleh Lembaga Masyarakat Adat bukan syarat wajib untuk membuat sertifikat tanah, surat pelepasan adat hanya sebagai dokumen pendukung saja. Ketika pemohon bisa menunjukkan bukti kepemilikkan seperti akta jual beli, atau keterangan yang lainnya, pengajuan bisa diproses. Namun dari pihak Lembaga Masyarakat Adat mengatakan suatu tanah ulayat tidak boleh diproses untuk membuat sertifikat bila tidak memiliki surat pelepasan adat. 
Perbedaan perspektif juga terjadi terkait proses pembuatan Surat Pelepasan Adat, Lembaga Masyarakat Adat tingkat Kabupaten menyampaikan setelah Lembaga Masyarakat Adat Imbuti membuat surat pelepasan, seharusnya diserahkan ke Lembaga Masyarakat Adat tingkat Kabupaten untuk disahkan, kemudian baru bisa dilanjutkan ke BPN untuk di proses untuk membuat sertifikat, selama ini yang terjadi tidak diserahkan ke LMA Kabupaten, sehingga banyak terjadi kasus surat pelepasan diatas pelepasan itu. Namun Ketua Lembaga Masyarakat Adat Imbuti membantah hal tersebut, beliau menyampaikan bahwa setelah mereka membuat surat pelepasan tidak perlu dilenjutkan ke Lembaga Masyarakat Adat tingkat Kabupaten, langsung saja ke Kelurahan dan kemudian ke BPN.

2. Aksesibilitas Aktor

Aksesibilitas aktor merupakan hal yang penting dalam proses penyelesaian kasus sengketa tanah ulayat, hal ini karena ada banyak pihak yang terlibat di dalamnya. Tanpa aksesibilitas yang mudah antar aktor yang terlibat dalam proses penyelesaian terkait sengketa tanah ulayat, tentunya permasalahan tersebut akan sulit untuk diselesaikan. Salah satu faktor penting dalam upaya penyelesaian suatu permasalahan adalah aksesibilitas yang mudah dan baik antar aktor. Sejauh ini aksesibilitas antar aktor dalam upaya penyelesaian masalah sengketa tanah ulayat di Kota Merauke berjalan dengan cukup baik. Diketahui bahwa bentuk aksesibilitas antar aktor dalam penyelesaian permasalahan terkait tanah ulayat adalah komunikasi antar aktor yang terlibat seperti Lembaga Masyarakat Adat, Badan Pertanahan dan Pengadilan Negeri berjalan dengan baik dan tidak rumit, hal ini dibuktikan ketika terjadi sengketa tanah ulayat "surat pelepasan diatas pelepasan" pihak Badan pertanahan berkomunikasi dengan Lembaga Masyarakat Adat untuk mediasi dan menyelidiki surat pelepasan mana yang benar.

Selain itu ketika ada proses peradilan di Pengadilan Negeri terkait kasus sengketa yang menyangkut hak ulayat, dalam pertimbangan putusan pengadilan, pada tahap pembuktian pihak Pengadilan Negeri berkomunikasi dengan pihak Lembaga Masyarakat Adat untuk memediasi kedua belah pihak. Dalam upaya penyelesaian sengketa tanah ulayat selalu mengutamakan mediasi dengan melibatan para aktor dalam proses penyelesaiannya.

3. Kemampuan Aktor dalam mengambil Tindakan

Dalam menyelesaikan suatu permasalahan, kemampuan aktor dalam mengambil tindakan sangatlah penting, atas dasar rasionalitas tindakan sosial, Max Weber membedakan dalam empat kategori (Turner, 2012) yaitu;

a) Zweek Rational/Tindakan Rasional Instrumental, yaitu tindakan yang dilaksanakan setelah melalui tindakan matang mengenai tujuan dan cara yang akan ditempuh untuk meraih tujuan.

b) Wert Rational/Tindakan Rasional Nilai, dalam wert rational, tindakantindakan sosial ditentukan oleh pertimbangan atas dasar keyakinan individu 
pada nilai-nilai estetis, etis dan keagamaan, manakala cara-cara yang dipilih untuk keperluan efisiensi mereka karena tujuannya pasti yaitu keunggulan.

c) Affectual Rational/dipengaruhi oleh Emosi (Afeksi), Tindakan ini dilakukan seseorang berdasarkan perasaan yang dimilikinya, biasanya timbul secara spontan karena mengalami suatu kejadian yang sebagian besar dikuasai oleh perasaan atau emosi tanpa perhitungan dan pertimbangan yang matang.

d) Tradisional Rational/Tindakan karena kebiasaan, Tindakan sosial semacam ini bersifat rasional, namun sipelaku tidak lagi memperhitungkan proses dan tujuannya terlebih dahulu, yang dijadikan pertimbangan adalah kondisi atau tradisi yang sudah baku dan manakala baik itu cara-caranya dan tujuantujuannya adalah sekedar kebiasaan.

Dalam upaya untuk menentukan tindakan dalam penyelesaian terkait sengketa tanah ulayat, Lembaga Masyarakat Adat menggunakan cara peradilan adat dengan musyawarah adat guna mendapatkan fakta-fakta yang digunakan sebagai pertimbangan untuk menentukan tindakan yang akan diambil dalam upaya penyelesaian sengketa tanah ulayat. Ketika terjadi kasus "pelepasan diatas pelepasan" atau sebuah tanah memiliki dua surat pelepasan adat dengan dua pihak yang berbeda, maka tindakan yang akan diambil Lembega Masyarakat Adat adalah mengamankan pihak pertama artinya tanah itu menjadi hak pihak pertama.

Sejauh ini kemampuan Lembaga Masyarakat Adat (LMA) dalam menentukan tindakan terkait sengketa tanah ulayat di Kota Merauke masih belum optimal. Hal ini dikarenakan masih banyak kasus-kasus sengketa yang belum terselesaikan, bahkan ada beberapa kasus yang tidak kunjung mendapat jalan keluar meski telah dilakukan musyawarah, pada akhirnya kasus tersebut justru dikembalikan kepada kedua belah pihak untuk diselesaikan secara kekeluargaan.

\section{Kesimpulan}

Berbagai sengketa hak atas tanah mengalami perkembangan dari waktu ke waktu, baik menyangkut sengketa perebutan hak, sengketa status tanah maupun bentukbentuk sengketa yang lainnya. Di Kota Merauke kerap kali terjadi sengketa tanah ulayat dikalangan masyarakat, seperti masalah hak ulayat, sengketa batas, kekeliruan petunjuk batas dan pembayaran pelepasan tanah yang belum diselesaikan. Berdasarkan data yang diperoleh dari Unit Bina Mitra Polres Merauke terkait jumlah sengketa pertanahan 6 (enam) tahun terakhir yang terjadi di Merauke berjumlah 77 kasus dengan rincian: Tahun 2014 terjadi 12 kasus, tahun 2015 terjadi 8 kasus, tahun 2016 terjadi 13 kasus, tahun 2017 terjadi 8 kasus, tahun 2018 terjadi 11 kasus, dan tahun 2019 terjadi 25 kasus. Pada dasarnya masyarakat adat di Papua menyatakan bahwa semua tanah di Papua merupakan tanah hak ulayat, kecuali yang telah dialihkan dengan proses pelepasan adat, dengan diterbitkannya surat pelepasan tanah Adat oleh Lembaga Masyarakat Adat (LMA). 
Berdasarkan hasil penelitian dan pembahasan, maka dapat ditarik kesimpulan bahwa Peran Lembaga Masyarakat Adat (LMA) dalam Penyelesaian Sengketa Tanah Ulayat di Kota Merauke dapat dikatakan masih belum optimal hal ini dikarenakan dari keempat indikator masih ada kendala dalam proses pelaksanaannya.

Dalam proses Pendataan dan menginventarisir hak-hak milik, lembaga Masyarakat Adat belum melakukannya secara keseluruhan, hal ini dikarenakan terdapat transaksi jual beli yang dilakukan tanpa melalui Lembaga Adat. Hal tersebut menyebabkan terjadinya kasus sengketa kepemilikkan hak atas tanah ulayat, karena pendataan administrasi yang belum sistematis, menyebabkan terjadi tumpang tindih surat pelepasan adat dimana satu objek tanah memiliki dua surat pelepasan adat dengan orang yang berbeda, pada akhirnya hal tersebut menimbulkan konflik antara masyarakat yang sama-sama merasa memiliki hak atas tanah tersebut. Dalam upaya menyelesaikan sengketa tanah ulayat, Lembaga Masyarakat Adat belum dapat menjalankan fungsinya sebagai mediator secara optimal, hal ini dibuktikan dengan masih terjadi berbagai aksi "pemalangan" terhadap fasilitas-fasilitas umum yang bermasalah dengan hak ulayat. Lembaga Masyarakat Adat belum sepenuhnya menjalankan fungsinya untuk memediasi pihak-pihak yang bersengketa dalam rangka rekonsiliasi dan konsolidasi melalui proses musyawarah untuk menghasilkan putusan yang dapat melegakan semua pihak, yang pada akhirnya sebagian besar kasus belum menemukan titik tengah penyelesaian.

Upaya yang ditempuh oleh Lembaga Masyarakat Adat dalam menengahi masalah sengketa tanah ulayat adalah mempertemukan kedua belah pihak yang bersengketa, kemudian melakukan musyawarah guna mencari solusi yang terbaik. Meski demikian masih banyak kasus sengketa tanah ulayat yang belum dapat diselesaikan meski telah dilakukan musyawarah, dan pada akhirnya masalah ini dikembalikan kepada kedua belah pihak untuk diselesaikan secara kekeluargaan.

Sengketa tanah ulayat disebabkan beberapa hal diantaranya; permasalahan administrasi di masa lalu sebelum terbentuk Lembaga Masyarakat Adat (LMA), transaksi pemindahan kepemilikan tanah ulayat pada waktu itut tanpa ada bukti tertulis, sehingga dikemudian hari ahli waris dari pemilik tanah adat tersebut mengklaim memiliki tanah tersebut. Dari kesalahan administrasi di masalalu itu timbul berbagai permasalahan sengketa tanah di Kota Merauke seperti sengketa karena ada surat pelepasan diatas pelepasan jadi ada 2 (dua) surat pelepasan untuk satu obyek tanah, ada juga sengketa pelepasan dengan sertifikat. Konflik pertanahan seringkali terjadi karena status kepemilikan tanah atau wilayah tersebut, hal ini dikarenakan belum adanya pemetaan secara tertulis terkait dengan batasan wilayah adat. Untuk menentukan batasan wilayah, cara yang digunakan masih dengan kepercayaan turun-temurun yaitu dengan nama tempat, dan keadaan alam seperti batas pohon, atau batas sungai. Hal ini tentunya akan berpotensi menimbulkan konflik dikemudian hari, karena keadaan alam tentunya akan berubah dari waktu ke waktu hal ini tentunya akan mempengaruhi posisi batasbatas wilayah tersebut.

Terjadi perbedaan perspektif antara Lembaga Masyarakat Adat dengan Badan Pertanahan Nasional terkait Surat pelepasan tanah adat sebagai syarat untuk pembuatan 
sertifikat. Badan Pertanahan Nasional yang menyatakan surat pelepasan adat bukan merupakan syarat wajib untuk membuat sertifikat tanah, surat pelepasan adat hanya sebagai dokumen pendukung. Ketika pemohon bisa menunjukkan bukti kepemilikkan seperti akta jual beli, atau keterangan yang lainnya, pengajuan bisa diproses. Namun pihak Lembaga Masyarakat Adat mengatakan suatu tanah ulayat tidak boleh diproses untuk membuat sertifikat bila tidak memiliki surat pelepasan adat. Perbedaan perspektif juga terjadi terkait proses pembuatan Surat Pelepasan Adat, Lembaga Masyarakat Adat tingkat Kabupaten menyampaikan setelah Lembaga Masyarakat Adat Imbuti membuat surat pelepasan, seharusnya diserahkan ke Lembaga Masyarakat Adat tingkat Kabupaten untuk disahkan, kemudian baru bisa dilanjutkan ke BPN untuk di proses untuk membuat sertifikat, selama ini yang terjadi tidak diserahkan ke LMA Kabupaten, sehingga banyak terjadi kasus surat pelepasan diatas pelepasan itu. Namun Lembaga Masyarakat Adat Imbuti membantah hal tersebut, setelah mereka membuat surat pelepasan tidak perlu dilenjutkan ke Lembaga Masyarakat Adat tingkat Kabupaten, langsung saja ke Kelurahan dan kemudian ke BPN.

Aksesibilitas aktor sejauh ini berjalan dengan baik dimana aktor dalam hal ini Lembaga Masyarakat adat selalu berkomunikasi dengan pihak-pihak terkait seperti Badan Pertanahan Nasional dan Pengadilan Negeri ketika terjadi sengketa terkait hak tanah ulayat. begitupun sebaliknya pihak badan Pertanahan Nasional dan Pengadilan Negeri juga selalu melibatkan Lembaga Masyarakat guna Memediasi pihak-pihak yang bersengketa. Kemampuan Lembaga Masyarakat Adat (LMA) dalam menentukan tindakan terkait sengketa tanah ulayat di Kota Merauke sejauh ini masih belum optimal. Hal ini dapat dilihat dari masih banyak kasus-kasus sengketa yang belum terselesaikan, bahkan ada beberapa kasus yang tidak kunjung mendapat jalan keluar meski telah dilakukan musyawarah, pada akhirnya kasus tersebut justru dikembalikan kepada kedua belah pihak untuk diselesaikan secara kekeluargaan.

Berdasarkan hasil penelitian dan proses analisis Peran Lembaga Masyarakat Adat (LMA) dalam penyelesaian sengketa tanah ulayat di Kota Merauke, terdapat beberapa hal yang harus dibenahi agar Peran Lembaga Masyarakat Adat (LMA) dalam penyelesaian sengketa tanah ulayat di Kota Merauke dapat terlaksana dengan optimal. Atas dasar kondisi tersebut peneliti menyampaikan beberapa saran, yaitu:

1. Melakukan pemetaan wilayah dan batas-batas wilayah adat yang dituangkan secara tertulis pada sebuah Peta wilayah adat.

2. Merapihkan sistem administrasi di Lembaga Masyarakat Adat (LMA) terkait status tanah ulayat yang belum di lepaskan dan yang telah dilepaskan. Sehingga ketika terjadi sengketa yang mengklaim kepemilikan, dapat dilihat sebenarnya kepada pihak mana tanah tersebut dilepaskan secara adat.

3. Melakukan pendataan dan pemetaan secara akurat terkait kelengkapan administrasi kepemilikkan setiap Tanah ulayat yang dimiliki, sehingga dapat mencegah terjadinya sengketa kepemilikkan tanah ulayat dikemudian hari.

4. Membuat sebuah forum diskusi yang melibatkan semua unsur Instansi pemerintah Daerah, Lembaga Masyarakat Adat. Masyarakat adat, dan masyarakat lainnya, 
Erwin Nugraha Purnama, Kismartini dan Retno Sunu Astuti

dengan tujuan untuk dapat membuat sebuah rancangan produk hukum yang nantinya dapat mengatur secara spesifik tentang tata wilayah adat. 
Peran Lembaga Masyarakat Adat (LMA) Suku Marind dalam Penyelesaian Sengketa Tanah Ulayat Di Kota Merauke

\section{BIBLIOGRAFI}

Abbas, S. (2011). Mediasi Dalam Hukum Syariah, Hukum Adat Dan Hukum Nasional. Jakarta: Kencana Prenada Media Group. Google Scholar

Arikunto. (2010). Prosedur Penelitian: Suatu Pendekatan Praktik (Revisi). Jakarta: Rineka Cipta. Google Scholar

Aris, Lumangkun, A., \& Nugroho.R, J. (2014). Peranan Lembaga Adat Dalam Penyelesaian Konflik Lahan Pada Hutan Adat Di Desa Engkode Kecamatan Mukok Kabupaten Sanggau. Jurnal Kehutanan, 341-347. Google Scholar

Chomzah, H. (2004). Hukum Agraria (Pertanahan Indonesia). Jilid. 2. Jakarta: Prestasi Pustaka. Google Scholar

Goti, S. M. R. (2014). Peran Mosa Sebagai Lembaga Pemangku Adat Dalam Penyelesaian Sengketa Tanah Ulayat Melalui Upaya Perdamaian Bagi Masyarakat Hukum Adat Kecamatan Jerebu'u Kabupaten Ngada. Atma Jaya: Yogyakarta. Google Scholar

Hanafi, M. (2013). Kedudukan Musyawarah Dan Demokrasi Di Indonesia. Cita Hukum, 1(2), 95778. Google Scholar

Hutapea, E. (2018). Sengketa Tanah antar-perorangan tembus 6071 kasus. Www.Kompas.Com.https://properti.kompas.com/read/2018/12/18/125954021/seng keta-tanah-antar-perorangan-tembus-6071-kasus

Peraturan Mahakimah Agung Nomor 1 Tahun 2008 Tentang Prosedur Mediasi di Pengadilan, Pub. L. No. 1 (2008).

Peraturan Daerah Kabupaten Merauke Nomor 4 Tahun 2013 Tentang Pemberdayaan, Perlindungan dan Pengembangan Adat Istiadat Serta Lembaga Adat, Pub. L. No. 4 (2013).

Rahmadi, T. (2011). Mediasi Dalam Penyelesaian Sengketa Dengan Pendekatan Mufakat. Jakarta: Rajagrafindo. Google Scholar

Rukuni, T., Machingambi, Z., Musingafi, M. C. C., \& Kaseke, K. E. (2015). The Role of Traditional Leadership in Conflict Resolution and Peace Building in Zimbabwean Rural Communities: The Case of Bikita District. Public Policy and Administration Research, 5(3), 75-79. Google Scholar

Sopian, N. L. (2015). Informal Dispute Resolution Based On Adat Law: A Case Study Of Land Dispute In Flores, East Nusa Tenggara, Indonesia. Indonesian Law Review, 2, 106-122. https://doi.org/http://dx.doi.org/10.15742/ilrev.v5n2.157 Google Scholar

Sudantra, I. K., Putra Astiti, T. I., \& Dharma Laksana, I. G. N. (2017). Sistem Peradilan 
Erwin Nugraha Purnama, Kismartini dan Retno Sunu Astuti

Adat Dalam Kesatuan-Kesatuan Masyarakat Hukum Adat Desa Pakraman Di Bali. Jurnal Kajian Bali (Journal of Bali Studies), $7(1), \quad 85$. https://doi.org/10.24843/jkb.2017.v07.i01.p06 Google Scholar

Turner, B. S. (2012). Teori Sosial dari Klasik sampai postmodern. Yogyakarta: Pustaka Pelajar. Google Scholar

Unit Bina Masyarakat Polres Merauke. (2019). jumlah sengketa pertanahan 6 (enam) tahun terakhir di Merauke.

Yakin, H. (2013). Analisis Peran Aktor Dalam Formulasi Kebijakan Program Nasional Pemberdayaan Masyarakat Mandiri Perkotaan Di Kelurahan Kemijen, Kota Semarang. Public Policy and Management Review, 2(2), 91-100. Google Scholar

\section{Copyright holder:}

Erwin Nugraha Purnama, Kismartini, Retno Sunu Astuti (2021)

First publication right:

Journal Syntax Literate

This article is licensed under:

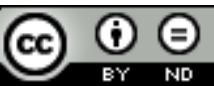

